\title{
Dansk identitetshistorie
}

\author{
Af Gustav Albeck
}

Dansk identitetshistorie I-IV. Redigeret af Ole Feldbak. C.A. Reitzels Forlag, Kфbenhavn 1992.

I august 1988 henvendte ledelsen af Det humanistiske Fakultet ved Københavns Universitet sig til et af sine yngre medlemmer, historikeren professor dr.phil. Ole Feldboek med opfordring til at etablere en forskningsgruppe af fortrinsvis fastansatte universitetslærere med henblik på tilvejebringelsen af et værk til belysning af dansk nationalbevidstheds historie. Eller, om man vil - af ængstelse for de følelsesladede reaktioner, som nationalfølelse og nationalbevidsthed, for ikke at sige nationalisme kunne fremkalde - en dansk identitetshistorie.

Man gav de fortrinsvis yngre forskere en frist på halvandet år (januar 1989 til 30. juni 1990) til udarbejdelsen, en frist, der dog blev forlænget til 31. december. Under alle omstændigheder en kort frist til den store opgaves løsning.

Ingen af de forskere, der blev opfordret til at deltage i projektet, var uvillige; men enkelte var optaget af andre opgaver. De blev erstattet af forskere fra Danmarks Lærerhøjskole, Nationalmuseet, Det Kgl. Bibliotek og Roskilde Universitetscenter, ligesom man under udarbejdelsen havde kontakt med Center for Kulturforskning ved Aarhus Universitet.

Som værket fremtræder er det en imponerende, ja næsten overvældende præstation; omfattende ialt ca. 2400 store og rigt og smukt illustrerede bøger. Hvert bind har en undertitel.

Første bind, der er på 424 sider, kaldes på godt forståeligt dansk: Faedreland og Modersmål 1536-1789. Andet bind: Et yndigt land - 1789-1848 er på 468 sider; tredje bind Folkets Danmark 1848-1940 afhandles på 673 sider, medens 4. bind med titlen Danmark og Europa er knapt så omfangsrigt, 589 sider. Med andre ord fire tunge kampesten på mere end 2500 næsten foliostore sider. Værket er $\mathrm{i}$ ingen henseende egnet til godnat-læsning.

Udstyret er smukt, solidt glat papir med læsevenlig skrift (undtagen i de mange fodnoter). Rosværdigt er det også, at man har givet plads til detaljerede indholdsregistre som indledning til hvert bind - samt oversigter over kilder og litteratur vedrørende hvert binds indhold, medens 4 . bind har et navneregister til det ganske værk, med henvisning specielt til aktive bidrag til problemet vedrørende danskheden. Der findes desuden oversigter over anvendt litteratur til enkelte af de større artikler. 
Som det fremgår af undertitlerne på de 4 bind, tilstræbes der kronologi ved placeringen, hvad man også vil bemærke ved et blik på titlerne på værkets mange større bidrag.

Bind I indledes af redaktøren, Ole Feldbaek, der præsenterer begrebet "National identitet « som den moderne betegnelse for nationalfølelse eller nationalbevidsthed, der har vundet indpas i forskningen i en tid, hvor gamle betegnelser som nationalitet og nationalfølelse - for ikke at tale om nationalisme er kommet i miskredit, siden nazisterne skamred de gamle travere - og tilstår iøvrigt, at der hidtil næsten ikke har været nogen dansk forskning inden for emnet. Det er i så henseende symptomatisk, at værket kun rummer eet, mindre, men til gengæld vægtigt, bidrag fra en (afdød) dansk forsker, professor Poul Bagge, der i 1963 offentliggjorde en artikel omhandlende "Nationalisme, antinationalisme og nationalfølelse i Danmark omkring $1900 \ll$. Forklaringen må if. Feldbæk være, at emnet indtil besættelsen var uden aktualitet og at uviljen mod de følger, som chauvinismen har haft, holdt forskeren på afstand af emnet. Først nu, da europæiseringstanken er kommet i forgrunden i den internationale politik, har de nationale problemer fået ny aktualitet og fundet vej til forskningen, ikke blot i Danmark. Herom handler bindets artikel nr. 2, professor Lorenz Rerups klare og meget sagkyndige opsats: »Hovedtræk i nationalismeforskningen, en kommenteret bibliografi«.

I sin introducerende artikel røber Feldbæk, at man under planlægningen af værket havde været inde på at lade 1700-tallet være det kronologiske udgangspunkt for identitets-analysen ud fra en antagelse om, at national identitet først på det tidspunkt bliver et anliggende for samfundsgrupper uden for magthavernes kreds. Man har med andre ord været fristet til at bygge fremstillingen af nationalitetsfølelsen til tiden o. den store franske revolution - et synspunkt, man ofte træffer i den mondæne presse, men som næppe er holdbart, for ikke at sige i strid med virkeligheden. Det taler Feldbæk til ære, at han i sin identitetshistorie har optaget seniorforsker ved Det kgl. Bibliotek, Harald Ilsøes meget oplysende afhandling »Danskerne og deres fædreland, holdninger og opfattelser ca. 1550-1700«. Han har i sit valg også kunnet støtte sig til slutningen af Rerups artikel, der med støtte af Oxfordprofessor Anthony D. Smiths resultater i værket The Ethnic Origins of Nations peger på moderne teorier om nationers (etniske) oprindelse, og bl.a. tyder på gammel national bevidsthed i nationer som Danmark og Island.

Feldbak præger i høj grad værkets første del bl.a. med en stor og meget givende afhandling om Fædreland og Indfødsret, 1700-tallets danske identitet, mens universitetslektor Vibeke Winge leverer en optakt til Feldbæks afhandling med en artikel omhandlende dansk og tysk i 1700-tallet. 
Som et supplement skildrer kunsthistorikeren Karin Kryger Dansk identitet $\mathrm{i}$ nyklassicistisk kunst, nationale tendenser og nationale særpræg 1750-1800.

Bind 2, med undertitlen Et yndigt Land, 1789-1848 indledes med en redegørelse for den såkaldte »Tyskerfejde « 1789-90, den første nationale konfrontation. Artiklen er udformet af Ole Feldbæk og Vibeke Winge. Sidstnævnte fortsætter skildringen af det efterhånden anspændte forhold mellem dansk og tysk i perioden 1790-1848, mens de følgende artikler er af litteraturhistorisk karakter. Fleming Conrad gør meget udførligt rede for den praktisk talt mislykkede konkurrence om tilvejebringelsen af en dansk nationalsang.

Her dukker navnet Grundtvig op, der ganske vist ikke deltog i konkurrencen, men hvis sang »Langt højere Bjerge« - skrevet til afskedsgildet for Trane - har bevaret et liv og stadig hører til blandt den folkelige sangs mest populære klassikere. Conrad har også skrevet kapitlet om den nationale litteraturhistorieskrivning 1800-1861. Og det er der mere gods i.

Bindet rummer desuden et meget klart kapitel om »Skole og identitet 1789-1848« samt en fast og velskreven afhandling af Rerup: Fra litterær til politisk skandinavisme. Udvikling og udbredelse fra 1808 til 1845.

Bind III, værkets omfangsrigeste og mest spændende har undertitlen: »Folkets Danmark. 1848-1940«. Det spænder over Flemming LundgreenNielsens næsten 200 sider store skildring af Grundtvigs danskhed - en hel bog for sig - videre en næsten lige så omfangsrig afhandling af lektor ved Musikhistorisk Institut ved Københavns Universitet Niels Martin Jensen om Niels W. Gade og den nationale tone med undertitlen: Dansk nationalromantik $i$ musikalsk belysning, en afhandling, der sandt nok har særlig adresse til musikkendere, men som kaster lys over et grundproblem, der for så vidt også gælder digtning og malerkunst.

Det var vistnok maleren Harald Giersing, der i den Første Verdenskrigs dage formulerede det ofte brugte (og til andre kunstnere henførte) paradox: »god kunst er national, al national kunst er dårlig «. Men ligesom digtningen i romantikkens dage ofte så et mål $\mathrm{i}$ at udtrykke nationale ejendommeligheder ikke blot $\mathrm{i}$ emnevalg, men også $\mathrm{i}$ form - ved at låne temaer fra folkedigtningen (hos os specielt den rige skat af folkeviser), søgte tonekunstnerne i højromantikkens tid inspiration fra fortidige sange og dansemelodier. Og hvad det angår er Gade, Ossianouverturens komponist, og Mendelsohns ven, dansk tonekunsts berømteste kunstner et naturligt valg.

Af en helt anden karakter er de bidrag som det store 3. bind rummer, der belyser nationalitetsideens indflydelse på den politiske, sociale og økonomiske udvikling i tiden fra 1840-1940, og som belyses i et nyt tæt opbygget afsnit om Folkestyre og danskhed. Massenationalisme og politik 1848-1866, skrevet med Lorenz Rerups faste hånd samt afdøde professor Poul Bagges 
klare redegørelse for Nationalisme, antinationalisme og nationalfølelse $i$ Danmark omkring 1900.

Hertil føjer sig en detaljerig fremstilling af Det nationale synspunkt på den фkonomiske udvikling 1888-1914 skrevet af stipendiat ved Institut for $\emptyset$ konomisk Historie ved Københavns Universitet Hans Kryger Larsen.

Hermed er skildringen nået frem til vort århundrede og dets brydninger mellem kosmopolisme og nationalisme, og ikke mindst udbredelsen og væksten af en voksende borgerliggørelse og en dermed forbundet langsomtvoksende følelse af samhørighed med nationen. Udviklingen i Danmark skildres fængslende af Niels Finn Christiansen, der er lektor ved Center for Arbejderkulturstudier ved Københavns Universitet. Forfatteren samler sin stofrige skildring i en spændende fremstilling med hovedtitlen: Socialismen og fadrelandet, og undertitlen Arbejderbevagelsen mellem internationalisme og national stolthed 1871-1940 og dokumenterer klart, at den offentlige bevidsthed om danskhed og tilslutning til det parlamentariske demokrati først fæstnede sig i arbejderbevægelsen i løbet af besættelsestidens første årti; et tydeligt eksempel på identiteten kan være betinget af begivenheder som krige og revolutioner, men formentlig også af udefinerbare (psykologiske?) forudsætninger.

Værkets fjerde og sidste bind, der bærer undertitlen »Danmark og Europa«, er for størstedelen skrevet af docent ved Institut for dansk Sprog ved Danmarks Lærerhøjskole Thorkild Borup Jensen og former sig som en række kapitler og underkapitler, der, som hovedtitlen nævner, samler sig om Besættelsestidens digte og sange som udtryk for national oplevelse og bevidsthed; det tager sit udgangspunkt $i$ to udsagn fra henholdsvis den nu næsten glemte forfatter Johannes Smith og den svenske etnolog Orvar Löfgren. Smith hævder at »med den nationale samhørighed har det sig som med helbredet, kun når det trues, kan det en overgang optages i bevidstheden«, mens etnologen mener at vide, at »nationalkänslan är en känsla, som aktiveras situationellt«.

Om de to udsagn giver en udtømmende forklaring på forekomsten af nationalbevidsthed og kærlighed til fædrelandet, hersker der - som allerede nævnt i denne anmeldelse - voksende tvivl - ikke blot hos samfundsforskere og etnologer, men også hos digtere, hvad et væld af de digtcitater, der findes i hans 535 sider lange fremstilling dokumenterer.

Det fortjener al mulig anerkendelse, at der er fremkommet en omfattende præsentation af den poesi, som besættelsestiden inspirerede til; men en begrænsning, der i højere grad tog hensyn til texternes kunstneriske kvalitet, burde nok have præget det voluminøse kapitel. Det bliver de gode digte, som også i fremtiden vil give folket den nationalbevidsthed, som kommende slægter næppe undgår truende konfrontationer med. 
Når det store værk om Danskheden - sådan burde det vel i virkeligheden kaldes - bliver anmeldt i Grundtvig-Studier, er det selvsagt fordi N.F.S. Grundtvig er hovedpersonen i den udvikling, den proces, som indadtil gjorde den danske stat fra et dynastisk monarki - omfattende flere nationaliteter især tyskere - til et nationaldemokrati, et lille folk i et lille land, hvis fremtid som en selvstændig stat måtte synes usikker.

Helt naturligt måtte det blive en så fortjenstfuld og kyndig yngre forsker som docent i dansk litteratur ved Københavns Universitet dr. phil Flemming Lundgreen-Nielsen, der fik til opgave at forme det centrale kapitel om, som han klart og umisforståeligt har givet overskriften Grundtvig og danskhed. Den store afhandling, en hel bog om emnet, vil uden tvivl blive læst med stort udbytte og megen glæde af alle, der føler sig påvirket af et åndsmenneske, der både var kristendommens store defensor i en kritisk tid - og den folkelige danskheds formidler og talsmand i en svær og skæbnerig tid, da tvivl om fremtiden måtte vendes til tro og håb.

Hovedtrækkene i Grundtvigs liv og virke er kendt af alle, som interesserer sig for Grundtvigs virke, og det er ret så mange. Ingen er i tvivl om hans betydning for udbredelsen af hans begreb folkelighed - som det fæstnede sig hos store dele af nationalstaten, og især slog rod og bredte sig gennem folkehøjskolen, selvom hans store planer om akademiet i Sorø eller det nordiske super-universitet i Göteborg aldrig skulle blive mere end en drøm. Først og fremmest var han digter, nogle mener endda vor største digter, men også i nogen måde sin samtids profet.

Som en slags profet fremstod han i dagene omkring det berømte møde på Skamling i 1844; men sandelig også i sit virke som stifter, formand og debatindleder i Danske Samfund 1839-44. Lundgreen-Nielsens afsnit om denne mærkelige institution - Det store afsnit om »samfundets stiftelse og virke« (p. 31-79) herom, der i høj grad bygger på politirapporter om mødernes forløb - et materiale, hvis eksistens Vagn Wåhlin har henledt opmærksomheden på - er værkets fornøjeligste læsning, glimrende egnet til at føre læseren ind $\mathrm{i}$ såvel tid som stil.

Om den profetiske side af sin gerning udtalte Grundtvig så sent som i 1866, da han som medlem af Rigsdagen stemte mod forslaget om det indskrænkede forslag til en ny grundlov: »Jeg veed nok, at de Høilærde blot for Løier eller med en vis Spydighed (har) kaldt mig »Spaamanden«, undertiden endogsaa »Spaakvinden«, men jeg veed ogsaa (at) der er stor Forskjel paa, hvoraf man spaaer, og jeg veed, jeg har aldrig spaaet af Streger i Haanden eller af Stjerner paa Himlen, men kun af den Oplysning vi alle kunne faae ved at agte vel paa Folkenes Art og Æt, paa Tidernes Løb og Tidernes Tegn, hvad de Høilærde sjelden værdige deres Opmærksomhed, men som jeg fra Ungdommen af har skjænket hele min«. - 
Jeg har ved en tidligere lejlighed fremdraget dette udsagn, (i indledningen til min bog »Grundtvig og Norden«), og finder anledningen til på ny at fremdrage det $i$ forbindelse med omtalen af noget jeg mangler i LundgreenNielsens ellers så perfekte kapitel om Grundtvigs danskhed.

Det forekommer mig, at han går lovlig let over den unge Grundtvigs syn på danskhed, og at der derfor mangler en smule af forklaringen på, hvorfor Grundtvig trods store skuffelser og bekymringer for landets og folkets fremtid, ikke kunne slippe forventningen om, at fædrelandet alligevel kunne se hen til en lys fremtid.

Jeg kunne tænke mig ved anden lejlighed at tage en diskussion op med Lundgreen-Nielsen og andre Grundtvig-forskere om de ret mange faser, som den unge Grundtvigs tanker om fædrelandet havde, hvor svært det var for ham at få sig placeret i danskheden. En overgang havde han fornemmelsen af at være norsk af sind og temperament. Allerede fra den tid karakteriserede han danskheden som en kvinde.

Måske savnede han som ung oplevelsen af et tilhørsforhold til det olddanske - fordi han i sin opvæksttid var knyttet til Jylland: Hans første poetiske Danmarksbillede er som bekendt forbundet med hans store digt Et Blad af Jyllands Rimkrønike. Men forøvrigt var hans jyskhed knyttet til hans tidlige fornemmelse af at hans temperament var norsk. Og det vil atter sige, at hans identitet - for at bruge modebetegnelsen - var betinget af tvillingriget. Det var en af grundene til at han reagerede voldsomt på begivenhederne i Norge i 1814.

En anden var, at han havde følt, at Gud havde kaldt ham til Norge, da han 1813 læste, at præstekaldet til Agger var ledigt. Her var han overbevist om, at han skulle virke med til at 6 . menighed, Philadelfia-menigheden,

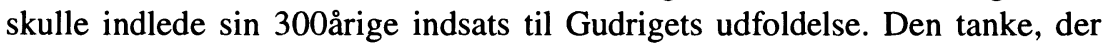
havde lynslået ham i efteråret 1810, at de syv breve i Apokalypsen indeholdt forudsigelser om syv store folkemenigheder, hver af 300 års varighed, som afspejlede sig i menneskehedens historie, forlod ham aldrig. Hans extatiske optræden i tiden omkring afståelsen af Norge forklares derved, ikke mindst fordi han mente at have fået vished for, at Gud kaldte ham til præstegerningen i Norge.

Så meget hårdere blev hans skuffelse, da drømmen om Phildelphiamenigheden brast. - Men han glemte den ikke; han vender nu og da tilbage til den og lader den få poetisk iklædning så sent som i det mærkelige digt »Christenhedens Syvstjerne« - udgivet 1860.

Det forekommer mig uigendriveligt, at det er troen på, at det er Danmark, den endnu levende gren af det gamle nordiske storrige, der med tiden skal bringe Kristendommen til sejr, der spøger bag Grundtvigs slutbemærkninger til supplementet til hans Verdenshistorie (1869). »Det Folkefærd, som skulde være skabt og skikket hertil, maatte, som vore høinordiske Fædre, 
selv i deres Hedenskab stole paa et guddommeligt Forsyn, der styrede Tidens L $\varnothing b$ til et evigt Gyldenaar, eller som Danskerne i deres Hedenskab, forgude Hjertet i sin aandelige Enkestand, men ingen af Delene findes hos andre Hedninger, og derfor vil al Verdens Magt ikke kunne forhindre, hvad den almægtige Gud aabenbar har forberedt i vort Fæderneland og ingen andensteds paa Jorden «.

Man får næppe den fulde forklaring på den styrke, han havde i behold, da Grundtvig i en oldings alder stædigt forfægtede sin tro på, at Danmark trods sit smertende tab, gik ind til en lysere fremtid.

\section{Af Gustav Albeck}

„På sporet af dansk identitet«, red. Flemming Lundgreen-Nielsen. Forlaget Spektrum. Kbh. 1992.

Umiddelbart efter fremkomsten af storværket om den danske identitet fremkom på forlaget Spektrum en meget mindre og lettere læselig bog med navnet »På sporet af den danske identitet«. Den var redigeret af docent, dr. phil. Flemming Lundgreen-Nielsen, der i et kort og klart formuleret indledningsafsnit stiller og besvarer det aktuelle spørgsmål: »Danskhed, hvorfor og hvorledes«?

Bogen rummer yderligere tre større kapitler fra samme forfatters hånd: »De lærdes og poeternes danskhed, 1520-1920«, »Danskhed i krige og kriser $1800-1864$ «, samt »De overvundnes litteratur 1864-1920«.

Fire andre bidragydere er Ole Feldbak, hvis emne er »Borgerskabets danskhed, 1720-1800«, Niels Finn Christiansen: »Folkets danskhed, 18641920«, Thorkild Borup Jensen: »Danskhed i litteraturens kaleidoskop, 19201990« og Henrik S. Nissen: »Nationalstaten og folket 1920-1990«.

De »nye« bidragydere er Thorkild Damsgaard Olsen, som behandler »Danskheden i oldtid og middelalder før 1536«, og professor ved Københavns Universitet, dr. phil. Per Østergaard, der stiller spørgsmålet: »Dansk identitet i fremtiden « og beroliger sine læsere med at sige, at han »ikke føler sig spor sikker på, at det skitserede europæiske perspektiv - som iøvrigt til sin tid næppe vil have meget at gøre med Maastricht-traktaten - vil blive realiseret ...«.

Den mindre bog kan ikke udtømmende karakteriseres som et slags kompendium til det store værk, men er i format og tone lettere tilgængeligt og interesseskærpende. En håndfuld spændende introduktioner, som $\mathrm{i}$ betragtelig grad vil skærpe lysten til at gå i gang med fordybelse i det mastodontagtige værk om Danskhed. 